Halaman 43 - 50

\title{
PENGARUH ASSESSMENT FOR LEARNING TERHADAP KEMAMPUAN BERARGUMENTASI SISWA SEKOLAH MENENGAH ATAS
}

\section{THE EFFECT OF ASSESSMENT FOR LEARNING TO ARGUMENTATIVE SKILL OF HIGH SCHOOL STUDENTS}

\author{
EKA RAKHMAWATI ${ }^{{ }^{*}}$, MURNI RAMLI, MUZZAYYINAH, RADEN RARA SAPARTINI ${ }^{2}$ \\ Program Studi Pendidikan Biologi \\ Fakultas Keguruan dan Ilmu Pendidikan \\ Universitas Sebelas Maret \\ J1. Ir. Sutami 36 A, Surakarta, 57126, Indonesia \\ *Corresponding Author: ekarakhmawati@ @student.uns.ac.id \\ ${ }^{2}$ Sekolah Menengah Atas Negeri 1 Surakarta
}

\begin{abstract}
The research aims to know the effect of Assessment for Learning (AfL) to argumentative skill of high school students. The research used a quasi experimental design with nonequivalent control group design. The design consists of control class and experiment class. Two clasess was randomly selected from 9 classes. The participants were 67 students from grade 10 of one high school in Surakarta. Data of argumentative skill was a pre-post test of AfL. The hypothesis test using t test and paired sample $\mathrm{t}$ test. The results of hypothesis testing showed that the significant value gained $0.000<0.05$, therefore $\mathrm{H}_{0}$ is rejected or $\mathrm{H}_{1}$ is accepted. The effect of Assessment for Learning (AfL) to argumentative skill of high school students is the significantly different between control and experimental class.
\end{abstract}

Keywords: Assessment for Learning, argumentative skill

\section{PENDAHULUAN}

Abad 21 merupakan era globalisasi yang ditandai dengan pesatnya ilmu pengetahuan dan teknologi. Kemajuan teknologi informasi dan komunikasi pada abad ini menyebabkan setiap orang bebas mengakses informasi dari berbagai belahan dunia. Kondisi pada abad 21 ini menuntut masyarakat global untuk memiliki penalaran sains dalam menghadapi setiap aspek kehidupan yang selalu dikaitkan dengan ilmu pengetahuan termasuk sains. Penalaran sains atau penalaran ilmiah berperan dalam proses pemecahan masalah (Moore \& Rubbo, 2012), sehingga memudahkan masyarakat dalam memahami dan mengaplikasikan sains dalam kehidupan.

Penalaran ilmiah dapat dilatih dengan mengembangkan kemampuan berargumentasi. Sadler \& Fowler (2006) menyatakan bahwa memverbalisasi melalui argumentasi menggunakan isu-isu sosial-ilmiah dapat mengembangkan penalaran ilmiah siswa. Kemampuan berargumentasi dalam penalaran ilmiah diistilahkan dengan argumentasi ilmiah. Argumentasi ilmiah adalah argumentasi formal berbasis bukti (Schen, 2007) yang melibatkan koordinasi data, klaim dan bukti untuk menghasilkan suatu pengetahuan (Chen, 2011). Argumentasi ilmiah berperan untuk memproduksi, mengevaluasi dan memajukan pengetahuan ilmiah (Bricker \& Bell, 2008) serta berperan bagi siswa untuk menjelaskan pemahaman ilmu pada tingkat yang lebih tinggi (Aufschnaiter, Erduran, Osborne \& Simon, 2008). Oleh karena itu, kemampuan berargumentasi ilmiah memiliki peran yang penting dalam penalaran ilmiah di abad 21 .

Fakta di lapangan menunjukkan bahwa kemampuan berargumentasi siswa di Indonesia masih perlu diperbaiki. Hal ini dapat dilihat dari profil kemampuan berargumentasi siswa SMA di Indonesia cenderung berargumentasi dengan tidak tepat dan tanpa bukti yang mendukung (Viyanti, 2015). Kemampuan berargumentasi berdasarkan informasi dan teori yang benar hanya dimiliki oleh sebagian kecil siswa yakni kurang dari $40 \%$ siswa (Handayani \& Sardiyanto, 2015; Pritasari, Dwiastuti, Probosari \& Sajidan, 2015). Berdasarkan hasil literasi sains siswa Indonesia pada PISA tahun 2012, kemampuan berargumentasi siswa Indonesia dalam bidang sains juga masih perlu diperbaiki.

Kemampuan berargumentasi siswa yang masih perlu perbaikan ini disebabkan oleh kegiatan belajar mengajar yang tidak memberikan kesempatan bagi siswa untuk berargumentasi. Kegiatan pembelajaran tersebut adalah pembelajaran yang terpusat pada guru dan tidak menggunakan teknik, metode, model dan pendekatan pembelajaran untuk melatih siswa berargumentasi. Pembelajaran tersebut menjadikan siswa tidak terlatih untuk berargumentasi. Oleh karena itu, solusi bagi permasalahan kemampuan berargumentasi dapat diselesaikan dengan mempertimbangkan pendekatan, metode, model dan teknik pembelajaran yang tepat untuk melatih kemampuan berargumentasi.

Pendekatan pembelajaran yang dapat melatih kemampuan berargumentasi salah satunya salah adalah pendekatan behavioristik. Pendekatan 
behavioristik menyatakan bahwa belajar adalah perubahan perilaku akibat adanya interaksi antara stimulus dan respons (Ormrod, 2008). Respon atau perilaku tertentu dapat terbentuk karena kondisi tertentu dengan menggunakan metode drill atau pembiasaan. Perilaku akan semakin kuat apabila diberikan penguatan dan akan menghilang apabila dikenai hukuman (Slavin, 2008). Salah satu teknik pembelajaran yang mengaplikasikan pendekatan behaviouristik adalah penggunaan assessment dalam pembelajaran. Assessment dalam pembelajaran yang diberikan secara konsisten merupakan kondisi tertentu sebagai suatu stimulus yang akan memberikan respon berupa perubahan perilaku seperti munculnya kemampuan berargumentasi siswa. Pengintegrasian asessment dalam pembelajaran juga dapat meningkatkan kualitas kinerja siswa dalam belajar (Smith, Wood, \& Knight, 2008).

Assesment yang diberikan sebagai solusi permasalahan berargumentasi berupa Assessment for Learning (AfL) untuk melatihkan kemampuan berargumentasi. AfL menekankan pada penggunaan feed back dalam pembelajaran sebagai umpan balik yang direfleksikan oleh siswa untuk mengetahui seberapa jauh kemampuannya dalam memahami pembelajaran (Basuki \& Hariyanto, 2014). Feed back pada AfL merupakan alat yang dipergunakan siswa untuk merefleksikan dan memaknai konsep pembelajaran sehingga siswa memperoleh pengetahuan yang benar. Pengetahuan yang diperoleh dari hasil hasil refleksi feed back AfL merupakan bekal bagi siswa untuk berargumentasi. Hal ini sesuai dengan pendapat Squire \& Mingfong (2007) yang menyatakan bahwa keterampilan berargumentasi dapat berkembang dengan baik pada diri siswa apabila siswa mampu memahami konsep dengan baik. Siswa harus memiliki pengetahuan yang cukup untuk dapat berpikir dan bernalar sehingga dapat menyampaikan suatu argumentasi. Feed back pada AfL juga dapat menjadi sarana motivasi yang efektif apabila diberikan dengan jelas, spesifik dan dalam waktu yang berdekatan dengan kinerja (Kulik \& Kulik dalam Slavin, 2011). Oleh karena itu, AfL merupakan alat untuk memperoleh pengetahuan untuk menunjang kemampuan berargumentasi.

AfL dapat meningkatkan kesuksesan siswa melalui proses mencari dan menginterpretasikan bukti untuk menentukan apa yang telah dipelajari, apa yang dikerjakan dan cara untuk mencapai tujuan (Stiggin \& Chappuis, 2006). AfL dapat melatih siswa berargumentasi melalui proses mencari alasan dan bukti untuk menguatkan argumennya. AfL juga memberikan informasi bagi guru dan siswa mengenai pembelajaran yang telah dilaksanakan untuk ditingkatkan pada pembelajaran selanjutnya. Oleh karena itu, penerapan AfL dalam pembelajaran diharapkan dapat meningkatkan kemampuan berargumentasi siswa. Kemampuan berargumentasi siswa yang meningkat diharapkan dapat berdampak pada peningkatan penalaran ilmiah dalam bidang sains termasuk biologi sehingga dapat membantu pengembangan ilmu biologi termasuk ilmu tentang plantae yang mengkaji tumbuhan untuk kelangsungan hidup manusia.

Penelitian ini bertujuan untuk mengetahui ada tidaknya pengaruh Assessment For Learning (AfL) terhadap kemampuan berargumentasi siswa sekolah menengah atas.

\section{METODE PENELITIAN}

Penelitian dilakukan di SMA N A Surakarta pada semester genap, yaitu bulan Maret sampai April tahun pelajaran 2015/2016. Populasi penelitian adalah semua siswa kelas $\mathrm{X}$ yang berjumlah 348. Sampel penelitian adalah siswa kelas X MIA 1 berjumlah 34 siswa dan X MIA 4 berjumlah 33 siswa yang diambil menggunakan teknik cluster sampling. Penelitan terdiri dari tiga tahap, yaitu persiapan, pelaksanaan, dan penyusunan laporan. Pelaksaan penelitian terdiri dari pelaksaan pretest, pelaksanaan pembelajaran plantae dan pelaksanaan posttest. Desain penelitian menggunakan kuasi eksperimen dengan nonequivalent control group design yang terdiri dari kelompok kontrol dan kelompok perlakuan. Kelompok kontrol adalah kelas X MIA 1 dan kelompok perlakuan adalah kelas X MIA 4 . Variabel penelitian terdiri dari variabel bebas yaitu, pembelajaran yang menggunakan AfL dan pembelajaran tanpa AfL sertavariabel terikat yaitu, kemampuan berargumentasi siswa.

Data penelitian berupa hasil pengukuran kemampuan berargumentasi yang meliputi claim, reasoning dan evidence yang diperoleh dari hasil pengujian pretest dan posttest. Data sekunder berupa hasil AfL yang diperoleh dari pengujian kemampuan berargumentasi menggunakan AfL. Metode pengumpulan data dilakukan dengan pretest dan posttest, tes AfL, dokumentasi kegiatan pembelajaran dan studi literatur terkait kemampuan berargumentasi siswa.

Pengujian hipotesis menggunakan uji $\mathrm{t}$ dan paired sample $t$ test dengan program SPSS. Pengujian hipotesis dilaksanakan setelah melakukan uji prasyarat analisis yaitu uji normalitas menggunakan uji kolmogorov-smirnov dan uji homogenitas menggunakan uji Levene. Analisis data dilakukan dengan analisis kuantitatif menggunakan pengujian statistika inferensial.

\section{HASIL DAN PEMBAHASAN}

Hasil penelitian menunjukkan bahwa kemampuan berargumentasi siswa yang diukur menggunakan pretest dan posttest pada kelas 
perlakuan lebih tinggi dibandingkan dengan kelas kontrol yang ditunjukkan oleh Gambar 1 .

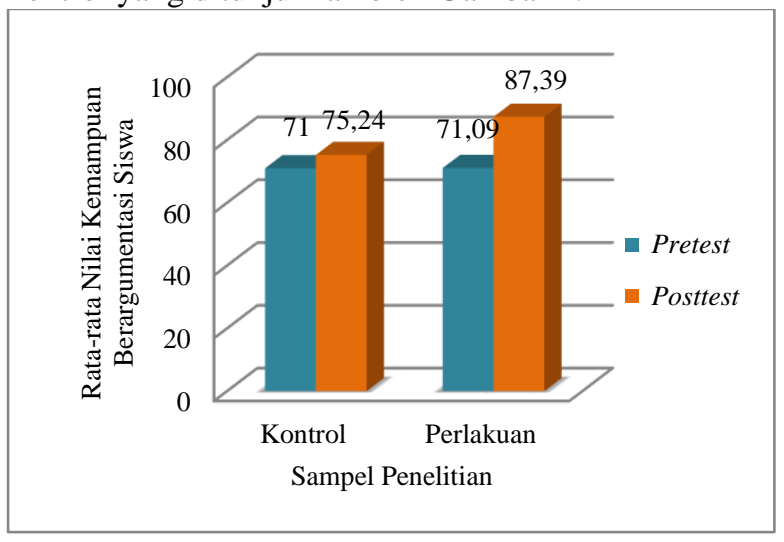

Gambar 1. Diagram Perbandingan Rata-rata Nilai Pretest dan Posttest Kemampuan Berargumentasi Siswa pada Kelas Kontrol dan Kelas Perlakuan

Gambar 1. menunjukkan bahwa pada kelas kontrol, perolehan rata-rata nilai pretest kemampuan berargumentasi sebesar 71 lebih rendah dibandingkan dengan perolehan rata-rata nilai posttest sebesar 75.24. Pada kelas perlakuan, rata-rata nilai pretest kemampuan berargumentasi sebesar 71.09 lebih rendah dibandingkan dengan perolehan rata-rata nilai posttest sebesar 87.39. Gambar tersebut juga menunjukkan bahwa rata-rata nilai pretest kemampuan berargumentasi pada kelas perlakuan sedikit lebih tinggi dibandingkan kelas kontrol, sedangkan rata-rata nilai posttest kemampuan berargumentasi pada kelas perlakuan lebih tinggi dibandingkan dengan kelas kontrol. Dengan demikian, pada kelas perlakuan terdapat perbedaan yang signifikan antara pretest dan posttest sedangkan pada kelas kontrol perbedaan antara pretest dan posttest tidak signifikan.

Tes AfL diberikan pada setiap akhir pertemuan pembelajaran plantae pada kelas perlakuan. Perolehan tes AfL pada setiap pertemuan pembelajaran plantae disajikan pada gambar 2.

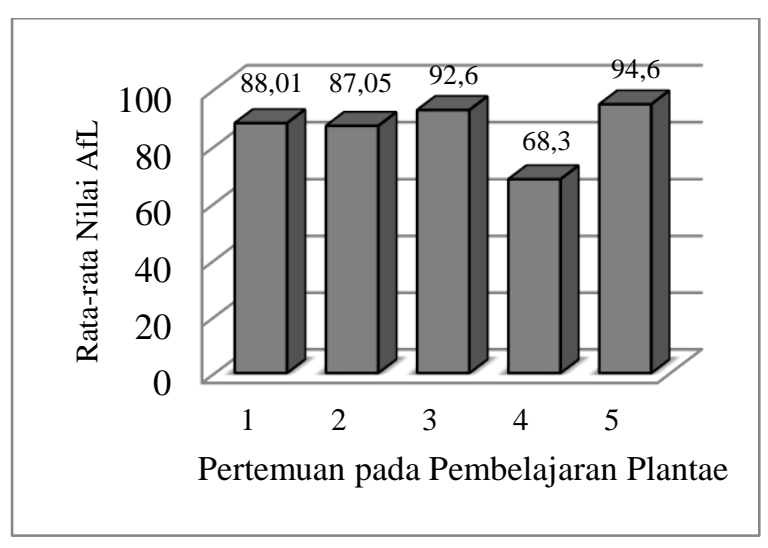

Gambar 2. Diagram Perbandingan Rata-rata Nilai Assesment For Learning Pertemuan ke- 1 sampai Pertemuan ke-5
Berdasarkan Gambar 2, perolehan rata-rata nilai AfL pada pertemuan 1 hingga pertemuan 5 berbeda-beda, yakni sebesar 88.01 pada pertemuan $1,87.05$ pada pertemuan $2,92.6$ pada pertemuan 3 , 68.3 pada pertemuan 4 dan 94.6 pada pertemuan 5 . Gambar tersebut juga menunjukkan bahwa nilai rata-rata AfL tertinggi diperoleh pada pertemuan 5 sebesar 94.6 dan rata-rata nilai AfL terendah diperoleh pada pertemuan 4 sebesar 68.3. Berdasarkan perhitungan rata-rata keseluruhan, diperoleh rata-rata nilai AfL sebesar 86.1.

Berdasarkan hasil pretest dan posttest, terlebih dahulu dilakukan uji prasyarat analisis untuk mengetahui data tersebut normal dan homogen atau tidak. Pengujian normalitas data ditunjukkan pada Tabel 1.

Tabel 1. Hasil Perhitungan Uji Normalitas Nilai Pretest dan Posttest Kemampuan Berargumentasi Siswa pada Kelas Kontrol dan Kelas Perlakuan

\begin{tabular}{clccc}
\hline Kelas & \multicolumn{1}{c}{ Tes } & Sig. & $\alpha$ & Hasil \\
\hline \multirow{2}{*}{ Kontrol } & Pretest & 0.202 & 0.05 & Sig $>\alpha$ \\
\cline { 2 - 5 } & Posttest & 0.104 & 0.05 & Sig $>\alpha$ \\
\hline \multirow{2}{*}{ Perlakuan } & Pretest & 0.992 & 0.05 & Sig $>\alpha$ \\
\cline { 2 - 5 } & Posttest & 0.299 & 0.05 & Sig $>\alpha$ \\
\hline
\end{tabular}

Berdasarkan Tabel 1, pengujian normalitas menggunakan uji kolmogorov-smirnov menghasilkan nilai signifikansi pada pretest dan posttest kelas kontrol dan kelas perlakuan yang lebih besar daripada $\alpha$. Hasil tersebut menunjukkan bahwa data kemampuan berargumentasi berdistribusi normal.

Pengujian homogenitas data ditunjukkan pada Tabel 2.

Tabel 2. Hasil Perhitungan Uji Homogenitas Nilai Pretest dan Posttest Kemampuan Berargumentasi Siswa pada Kelas Kontrol dan Kelas Perlakuan

\begin{tabular}{lcccc}
\hline \multicolumn{1}{c}{ Kelas } & Tes & Sig. & $\alpha$ & Hasil \\
\hline Kontrol & Pretest & 0.056 & 0.05 & Sig $>\alpha$ \\
\hline Perlakuan & Pretest & 0.678 & 0.05 & Sig $>\alpha$ \\
\hline
\end{tabular}

Berdasarkan Tabel 2, pengujian homogenitas menggunakan uji levene menghasilkan nilai signifikansi pada pretest dan posttest kelas kontrol dan kelas perlakuan yang lebih besar daripada $\alpha$. Hasil tersebut menunjukkan bahwa data kemampuan berargumentasi homogen.

Data pretest dan posttest kemampuan berargumentasi yang sudah diuji normalitas dan homogenitasnya menunjukkan bahwa data tersebut normal dan homogen. Oleh karena itu, dapat dilakukan uji hipotesis menggunakan uji $\mathrm{t}$ dan paired sample $t$ test untuk mengetahui pengaruh AfL terhadap kemampuan berargumentasi siswa. 
Uji t dilakukan untuk menguji perbedaan rata-rata data dari dua sampel yang berbeda. Adapun data yang diuji adalah data pretest pada kelas kontrol dan kelas perlakuan serta data posttest pada kelas kontrol dan kelas perlakuan. Pengujian hipotesis menggunakan uji t disajikan pada Tabel 3.

Tabel 3. Hasil Perhitungan Uji Hipotesis

Kemampuan Berargumentasi

Menggunakan Uji t

\begin{tabular}{lcccc}
\hline \multicolumn{1}{c}{ Data } & Sig. & $\alpha$ & Hasil & $\begin{array}{c}\text { Keputusa } \\
\text { n Uji }\end{array}$ \\
\hline $\begin{array}{l}\text { Nilai } \\
\text { pretest }\end{array}$ & & & & \\
$\begin{array}{l}\text { kelas } \\
\text { kontrol }\end{array}$ & 0.973 & 0.05 & $\begin{array}{c}\text { Sig }> \\
\alpha\end{array}$ & $\begin{array}{c}\mathrm{H}_{0} \\
\text { diterima }\end{array}$ \\
$\begin{array}{l}\text { kelas } \\
\text { perlakuan }\end{array}$ & & & & \\
\hline $\begin{array}{l}\text { Nilai } \\
\text { posttest }\end{array}$ & & & & \\
$\begin{array}{l}\text { kelas } \\
\text { kontrol } \\
\text { dan kelas } \\
\text { perlakuan }\end{array}$ & 0.00 & 0.05 & Sig & \\
\hline
\end{tabular}

Tabel 3. menunjukkan bahwa pengujian hipotesis pada nilai pretest kelas kontrol dan kelas perlakuan menghasilkan keputusan $\mathrm{H}_{0}$ diterima yang berarti tidak berbeda nyata antara pretest pada kelas kontrol dan kelas perlakuan. Tidak berbeda nyata dalam pengujian ini menunjukkan bahwa tidak terdapat pengaruh AfL terhadap kemampuan berargumentasi siswa. Tabel juga menunjukkan bahwa pengujian hipotesis pada nilai posttest kelas kontrol dan kelas perlakuan menghasilkan keputusan $\mathrm{H}_{0}$ ditolak atau $\mathrm{H}_{1}$ diterima yang berarti berbeda nyata antara posttest kelas kontrol dan kelas perlakuan. Berbeda nyata dalam pengujian ini menunjukkan bahwa terdapat pengaruh AfL terhadap kemampuan berargumentasi siswa.

Paired samples t test dilakukan untuk menguji perbedaan rata-rata dua data berpasangan (pretestposttest) dari kelompok sampel yang sama. Adapun data yang diuji adalah data pretest dan posttest pada kelas kontrol serta data pretest dan posttest pada kelas perlakuan. Pengujian hipotesis menggunakan paired samples t test disajikan pada Tabel 4
Tabel 4. Hasil Perhitungan Uji Hipotesis

Kemampuan Berargumentasi

Menggunakan Paired Sample t Test

\begin{tabular}{|c|c|c|c|c|}
\hline Data & Sig. & $\alpha$ & Hasil & $\begin{array}{c}\text { Keputusan } \\
\text { Uji }\end{array}$ \\
\hline $\begin{array}{l}\text { Nilai } \\
\text { pretest dan } \\
\text { nilai } \\
\text { posttest } \\
\text { kelas } \\
\text { kontrol } \\
\end{array}$ & 0.055 & 0.05 & $\begin{array}{c}\text { Sig }> \\
\alpha\end{array}$ & $\begin{array}{c}\mathrm{H}_{0} \\
\text { diterima }\end{array}$ \\
\hline $\begin{array}{l}\text { Nilai } \\
\text { pretest dan } \\
\text { nilai } \\
\text { posttest } \\
\text { kelas } \\
\text { perlakuan }\end{array}$ & 0.000 & 0.05 & $\begin{array}{c}\mathrm{Sig}< \\
\alpha\end{array}$ & $\mathrm{H}_{0}$ ditolak \\
\hline
\end{tabular}

Berdasarkan Tabel 4, pengujian hipotesis pada nilai pretest dan nilai posttest kelas kontrol menghasilkan keputusan $\mathrm{H}_{0}$ diterima yang berarti tidak berbeda nyata antara pretest dan posttest kelas kontrol. Tidak berbeda nyata dalam pengujian ini menunjukkan bahwa tidak terdapat pengaruh AfL terhadap kemampuan berargumentasi siswa pada kelas kontrol. Pengujian hipotesis pada nilai pretest dan nilai posttest kelas perlakuan menghasilkan keputusan $\mathrm{H}_{0}$ ditolak atau $\mathrm{H}_{1}$ diterima yang berarti berbeda nyata antara pretest dan posttest kelas perlakuan. Berbeda nyata menunjukkan bahwa terdapat pengaruh AfL terhadap kemampuan berargumentasi siswa pada kelas perlakuan.

Argumentasi dalam penjelasan ilmiah menurut McNeill \& Krajcik (2011) mencakup tiga komponen, yaitu claim, reasoning dan evidence. Claim adalah pernyataan yang menjawab pertanyaan awal. Reasoning adalah alasan yang menunjukkan bahwa data merupakan bukti yang mendukung claim. Evidence adalah bukti berupa informasi atau data ilmiah yang mendukung claim. membangun. Siswa SMA perlu memiliki kemampuan berargumentasi karena berperan untuk menghasilkan, mengevaluasi dan memajukan pengetahuan ilmiah sebagai komponen inti sains dalam dunia pendidikan (Bricker \& Bell, 2008).

Kemampuan seseorang dalam berargumentasi dapat dilatih melalui pemahaman struktur konseptual, mengembangkan dan mengevaluasi klaim serta berpartisipasi dalam proses-proses sosial yang membentuk pengetahuan (Duschl, 2008). Penelitian Zembal-Saul (2009) menyatakan bahwa argumen berbasis bukti dapat ditingkatkan melalui scaffolding argument dan penyusunan kerangka argument.

Menurut McNeill \& Krajcik (2009) guru dapat memberikan dukungan bagi siswa untuk mengembangkan argumentasi dalam penjelasan ilmiah dengan cara : 1) membuat kerangka eksplisit, 2) membahas alasan mengenai penjelasan 
ilmiah, 3) pemodelan untuk menyusun penjelasan ilmiah, 4) membahas persamaan dan perbedaan dengan penjelasan ilmiah sehari-hari 5) menyediakan kesempatan kepada siswa untuk menyusun penjelasan ilmiah, 6) memberikan kesempatan bagi siswa untuk mengkritik penjelasan siswa lain dan 7) memberikan umpan balik bagi siswa.

Berdasarkan tujuh cara untuk mengembangkan argumentasi dalam penjelasan ilmiah, terdapat lima cara yang sudah terpenuhi dalam penelitian. Cara pengembangan argumentasi yang sudah terpenuhi antara lain membuat kerangka ekplisit yaitu pada awal penelitian guru menjelaskan mengenai perbedaan kerangka claim, reasoning dan evidence kepada siswa sehingga siswa mampu membuat kerangka argumentasi yang mencakup claim, reasoning dan evidence. Pembahasan alasan mengenai penjelasan ilmiah sudah dilakukan dengan cara mendiskusikan dengan siswa mengenai alasan yang mendasari suatu pernyataan disertai dengan teori dan prinsip ilmiah yang mendukung. Pemodelan untuk menyusun penjelasan ilmiah dilakukan melalui pemberian contoh berargumentasi oleh guru. Guru menyediakan kesempatan kepada siswa untuk menyusun penjelasan ilmiah melalui kegiatan diskusi agar siswa dapat mengemukakan pendapatnya. Pemberian umpan balik bagi siswa dilakukan oleh guru pada AfL siswa melalui umpan balik lisan, tulisan dan intervensi guru dalam pembelajaran. Oleh karena itu, terdapat dua cara mengembangkan argumentasi yang belum terpenuhi yaitu menyediakan kesempatan bagi siswa untuk mengkritik penjelasan siswa lain dan membahas persamaan dan perbedaan dengan penjelasan ilmiah sehari-hari.

Cara pengembangan argumentasi melalui pemberian umpan balik dalam pembelajaran merupakan ciri khas dari assessment for learning (AfL). Menurut Berry (dalam Ng, 2016), salah satu prinsip AfL dalam pembelajaran adalah memberikan umpan balik untuk memfasilitasi siswa dalam belajar. AfL yang disertai dengan pemberian umpan balik pada penelitian ini dapat mempengaruhi kemampuan berargumentasi siswa.

Konten AfL dalam penelitian ini dirancang khusus untuk melatih kemampuan berargumentasi siswa berdasarkan rubrik kemampuan berargumentasi oleh McNeill \& Krajcik (2011). Setiap soal pada AfL mengandung komponen claim, reasoning dan evidence. Soal ini siswa menuntut siswa untuk mencari jawaban atas claim yang diberikan. Berdasarkan claim tersebut siswa harus mencari informasi atau data ilmiah yang merupakan bukti untuk mendukung claim. Pada tahap akhir siswa dituntut untuk mencari alasan pembenaran yang menunjukkan bahwa data merupakan bukti yang mendukung claim.
Soal AfL yang diberikan pada setiap akhir pertemuan terdiri dari soal pilihan ganda dan soal essay. Soal pilihan ganda memuat suatu pernyataan yang menuntut siswa untuk mencari jawaban benar dari pilihan jawaban yang telah disediakan. Setiap pilihan jawaban memuat claim, reasoning dan evidence. Pilihan jawaban tersebut melatih siswa untuk berargumentasi. Siswa yang memilih salah satu pilihan jawaban, berarti sudah menyampaikan argumentasi. Apabila jawaban benar maka argumentasi siswa benar, sedangkan apabila jawaban salah maka argumentasi siswa salah. Soal essay memuat suatu pernyataan dengan 3 sub soal, yaitu pada sub soal pertama, siswa dilatih untuk menyatakan claim benar atau salah berdasarkan pernyataan pada soal, kemudian pada sub soal kedua siswa dilatih untuk memberikan suatu alasan (reasoning) yang membenarkan claim dan pada sub soal ketiga siswa dilatih untuk memberikan bukti (evidence) yang berkaitan dengan alasan dan claim yang telah disebutkan.

Bentuk soal AfL yang terdiri dari soal pilihan ganda dan soal uraian merupakan faktor yang mendukung pelatihan kemampuan berargumentasi siswa. Setiap soal terdiri dari 5 butir soal dengan tiga soal pertama berupa pilihan ganda yang membantu siswa mengenali cara berargumentasi melalui pilihan jawaban argumentasi yang telah disediakan dan dua soal terakhir berupa esai yang membantu siswa mengembangkan cara berargumentasi melalui jawaban yang diberikan. Hal ini karena jawaban pada soal pilihan ganda bersifat pasti dan hanya menyediakan satu kemungkinan jawaban benar (Suwandi, 2011) sehingga siswa terbantu untuk mengetahui tipe soal AfL yang mengandung argumentasi. Tes esai menurut Tuckman (dalam Nurgiyantoro, 2009), merupakan suatu bentuk pertanyaan yang menuntut jawaban siswa dalam bentuk uraian menggunakan bahasanya sendiri. Hal ini akan membantu siswa dalam menguraikan jawabannya dalam bentuk kalimat argumentasi.

Soal AfL dikerjakan di rumah dalam waktu 2 hari dengan cara open book. AfL yang dikerjakan dengan cara open book dapat mempengaruhi hasil kemampuan berargumentasi siswa. Ahli konstruktivisme berpendapat bahwa pengujian secara open book akan meningkatkan keterlibatan siswa dalam pembelajaran melalui pencarian jawaban atas permasalahan yang diberikan (Williams, 2006). Oleh karena itu, siswa dapat mencari jawaban yang benar atas claim yang diberikan dari berbagai sumber informasi, kemudian dapat menemukan alasan dan bukti yang tepat dan mendukung claim sehingga mampu berargumentasi menggunakan claim, reasoning dan evidence yang tepat. Mengerjakan soal secara open book juga dapat mengurangi kecemasan siswa, sehingga siswa dapat menikmati pembelajaran dan mendorong siswa dalam belajar (Block, 2012) 
termasuk dalam mendorong siswa untuk berargumentsai.

Soal AfL yang telah dikerjakan dan dikumpulkan oleh siswa kemudian diperiksa dan diberikan umpan balik oleh guru. Guru menyerahkan umpan balik kepada siswa sehari setelah pengumpulan AfL, yaitu pada pertemuan selanjutnya dan sekaligus guru menyampaikan komentar terkait dengan perkerjaan siswa. Umpan balik tersebut merupakan umpan balik instruksional yang berupa informasi yang diberikan oleh agen seperti guru, teman sebaya, atau perangkat komputer yang menunjukkan kebenaran, ketidaktepatan dan cara-cara untuk meningkatkan kinerja atau pemahaman (Hattie \& Timperley, 2007). Umpan balik dalam penelitian ini hanya diberikan oleh guru kepada siswa. Penggunaan umpan balik dalam pembelajaran memberikan efek positif pada hasil belajar dibandingkan tidak ada pemberian umpan balik (Alfieri, Brooks, Aldrich, \& Tenenbaum, 2011), dalam penelitian ini memberikan dampak positif terhadap kemampuan berargumentasi siswa. Guru memberikan umpan balik dalam bentuk lisan, tulisan dan intervensi guru dalam pembelajaran.

Penyampaian umpan balik lisan dilakukan pada pertemuan selanjutnya yaitu pada pendahuluan pembelajaran. Umpan balik lisan ini dimaksudkan untuk memberikan gambaran mengenai hasil pekerjaan AfL secara umum dan keseluruhan.. Guru memberikan umpan balik lisan dengan media power point untuk menunjukkan soal dan jawaban AfL yang benar kepada siswa dengan cara membahas kembali soal AfL yang telah dikerjakan siswa. Pemberian umpan balik lisan pada penelitian ini kurang tepat untuk melatih kemampuan berargumentasi karena hanya memberikan review mengenai soal AfL dengan cara membahas secara umum. Umpan balik lisan yang seharusnya diberikan berupa umpan balik korektif dengan mengoreksi kesalahan konsep dan argumentasi pada AfL serta umpan balik positif dengan memberikan penguatan dan penjelasan lebih lanjut mengenai jawaban siswa yang sudah benar (Ellis, 2009). Umpan balik lisan yang diberikan secara korektif dan positif merupakan upaya remedial teaching yang dilakukan oleh guru untuk memperbaiki kesalahan pada pekerjaan AfL sebelumnya.

Umpan balik tulisan bersifat pribadi karena diberikan pada lembar pekerjaan AfL setiap siswa. Umpan balik untuk mengukur kualitas pribadi hanya dapat bermanfaat apabila disertai dengan informasi yang berkaitan dengan tugas dan proses pembelajaran (Hattie \& Timperley, 2007). Oleh karena itu, guru memberikan umpan balik tulisan yang berisi informasi mengenai penguatan bagi jawaban yang benar dan pembenaran atau perbaikan bagi jawaban salah serta komentar terhadap cara penulisan argumentasi sehingga siswa dapat memperbaiki kemampuan berargumentasinya. Umpan balik tulisan pada penelitian ini bersifat langsung yaitu guru memberikan arahan secara langsung kepada siswa untuk mengoreksi dan memberitahu siswa mengenai apa yang perlu direvisi (Shute, 2008). Pemberian umpan balik ini sebaiknya disertai dengan umpan balik tidak langsung agar siswa belajar aktif untuk membangun konsep berargumentasinya sendiri dengan bimbingan dari guru yaitu melalui pertanyaan penuntun agar siswa berpikir lebih lanjut untuk memecahkan masalahnya sendiri.

Umpan balik AfL juga diberikan dalam bentuk intervensi guru dalam pembelajaran. melalui kegiatan tanya jawab untuk membimbing siswa dalam menyampaikan argumentasi. Tanya jawab dengan siswa dilakukan selama proses pembelajaran dengan cara memberikan pertanyaan penuntun yang mengandung kata kunci untuk melatih kemampuan berargumentasi. Kata kunci yang digunakan oleh guru adalah kata tanya "mengapa?", “apa buktinya?", “apa perbedaannya?”, “bagaimana ciri khasnya?”. Kata kunci ini berfungsi untuk mendorong keingintahuan siswa secara lebih dalam untuk mencari alasan dan bukti yang mendukung pernyataan yang disampaikan.

Guru memberikan umpan balik disertai konfirmasi menggunakan reinforcement berupa pujian atas ketepatan jawaban siswa dengan menyampaikan kata-kata "good job"," good evidence", "tepat sekali", "jawaban yang bagus", "Cerdas". Kata-kata pujian ini dapat menjadi motivasi dan semangat bagi siswa untuk belajar berargumentasi (Shute, 2008). Tseng \& Tsai (2007) mengemukakan bahwa umpan balik afektif dengan mengekspresikan perasaan positif seperti memberikan pujian akan lebih bermanfaat bagi siswa SMA untuk mengembangkan kemampuan yang lebih baik.

Guru dan siswa memperoleh manfaat dari penggunaan umpan balik dalam pembelajaran. Umpan balik bagi guru bermanfaat untuk mengetahui keefektifan pengajaran serta membantu guru dalam memahami pemikiran siswa dan kekeliruan pemahaman siswa sehingga dapat menentukan langkah perbaikan yang tepat (Slavin, 2011). Menurut Sato \& Atkin (dalam Slavin, 2011), umpan balik bagi siswa bermanfaat untuk mengetahui kekuatan dan kelemahan dalam pembelajaran sehingga dapat menentukan tindak lanjut untuk meningkatkan prestasi belajarnya yang dalam hal ini bermanfaat untuk memperbaiki kemampuan berargumentasi.

Menurut Kulik \& Kulik (dalam Slavin, 2011), umpan balik dapat menjadi sarana motivasi yang efektif apabila diberikan dengan jelas dan spesifik serta diberikan dalam waktu yang berdekatan dengan kinerja. Umpan balik pada penelitian ini 
diberikan segera setelah siswa menyelesaikan AfL sehingga siswa segera mengetahui kekurangan dan kelebihan dari pekerjaannya dan termotivasi untuk memperbaiki keterampilan berargumentasi melalui pelatihan AfL. Informasi mengenai umpan balik akan membantu siswa meningkatkan penulisan dibandingkan pemberian nilai tanpa penjelasan (Chappuis dalam Slavin, 2012). Pemberian umpan balik tidak menggunakan nilai pada hasil pekerjaan AfL siswa melainkan dengan memberikan komentar yang berisi informasi mengenai pekerjaan AfL siswa agar antar siswa tidak saling berkompetisi untuk mendapatkan nilai terbaik, namun fokus terhadap perbaikan dirinya diri berdasarkan komentar yang diberikan.

Cross \& Cross (dalam Slavin, 2011) menemukan bahwa siswa yang menerima umpan balik tertulis, bukan berupa nilai atau huruf, akan lebih mempercayai bahwa keberhasilan yang diperoleh ditentukan oleh usahanya sendiri, bukan diperoleh karena keberuntungan atau faktor eksternal lain. Hal ini dapat dijelaskan secara psikologi bahwa pada tahap awal diberikan kritik dan saran, siswa akan melakukan tindakan penghindaran (aversion) akibat perasaan tidak menyenangkan dari umpan balik yang diberikan. Selanjutnya akan muncul keingintahuan (curiosity) pada siswa terhadap permasalahan pada kritik dan saran umpan balik tersebut. Pada tahap berikutnya muncul perilaku toleransi (tolerance) untuk menahan perasaan tidak menyenangkan yang dirasakan, namun tetap berharap hal tersebut akan hilang dengan sendirinya. Tahapan selanjutnya yaitu muncul tindakan membiarkan (allowing) terhadap perasaan yang muncul akibat pemberian umpan balik. Pada tahap akhir akan muncul persahabatan (friendship) yakni siswa mulai bangkit dari perasaan tidak menyenangkan dan bersyukur atas atas kritikan dan saran yang diberikan sehingga mencoba memperbaiki kesalahan dalam pembelajaran sebelumnya. Kelima tahapan tersebut merupakan proses penerimaaan diri seorang siswa terhadap situasi dan emosi yang muncul setelah menerima umpan balik berupa kritik dan saran berdasarkan teori penerimaan diri yang dikemukakan oleh Germer (2009). Oleh karena itu, siswa yang telah mengalami proses penerimaan diri akan mulai percaya terhadap kemampuan dirinya sendiri.

Hasil penelitian mengenai AfL yang mempengaruhi kemampuan berargumentasi sesuai dengan teori yang dikemukakan Stiggin \& Chappuis (2006) yang menyatakan bahwa AfL dapat meningkatkan kesuksesan siswa melalui proses mencari dan menginterpretasikan bukti untuk menentukan apa yang telah dipelajari, apa yang harus dikerjakan dan bagaimana cara untuk mencapai tujuan yang diinginkan. Melalui soal AfL, siswa dituntut berpikir untuk menemukan alasan dan bukti atas pernyataan yang disampaikan sehingga siswa tidak menjawab pertanyaan dengan sederhana, melainkan perlu mencari lebih lanjut mengenai jawaban, alasan dan bukti yang menguatkan pendapatnya. Upaya pencarian lebih lanjut ini akan memunculkan perilaku berupa penyampaian gagasan dan ide mengenai jawaban, alasan dan bukti yang mendukung pendapatnya sehingga dapat mempengaruhi kemampuan siswa dalam berargumentasi.

AfL yang diberikan secara konsisten pada setiap pertemuan dapat melatih siswa dalam berargumentasi. Soal AfL menuntut siswa untuk menemukan alasan dan bukti yang mendukung pernyataan. Oleh karena itu, siswa perlu mencari lebih lanjut mengenai alasan dan bukti untuk menguatkan pernyatannya melalui studi literatur. Penemuan alasan dan bukti ini kemudian dirangkai dengan pernyataan dalam suatu kalimat argumentasi. Proses ini berlangsung secara berulang sehingga diduga telah membentuk kebiasaan baru atau budaya baru bagi siswa dalam berargumentasi. Tindakan intervensi pembelajaran berupa AfL yang diberikan berulang akan memberikan pola baru bagi siswa dalam merespon pertanyaan. Kemunculan pola baru ini dapat dijelaskan dengan teori behaviouristik.

Teori behaviouristik menyatakan bahwa seseorang telah belajar apabila mampu menunjukkan perubahan tingkah laku sebagai hasil interaksi antara stimulus dan respons (Baharudin \& Wahyuni, 2010). Perilaku akan semakin kuat apabila diberikan penguatan (reinforcement) dan akan menghilang apabila dikenai hukuman (punishment). Berdasarkan teori behaviouristik Pavlov (1903) mengenai pengkondisian klasikal, AfL dalam pembelajaran merupakan pengkondisian tertentu yang dilakukan secara berulang sehingga memunculkan perilaku berupa kemampuan berargumentasi. Tindakan memperbaiki kesalahan berargumentasi berdasarkan umpan balik pada AfL diikuti dengan perubahan kemampuan berargumentasi yang lebih baik sehingga dalam situasi yang sama yaitu setelah diberikan umpan balik, seseorang akan mengulangi tindakan berupa memperbaiki kemampuan berargumentasinya. Hal ini sesuai dengan hukum law effect yang dikemukakan Thorndike (1911). Berdasarkan prinsip reinforcement dan punishment yang dikemukakan Skinner (1930), pemberian umpan balik AfL merupakan reinforcement positif yang akan meningkatkan perilaku munculnya kemampuan berargumentasi yang lebih baik.

Pemberian AfL dalam pembelajaran juga dapat ditinjau dari teori scaffolding Vygotsky. Scaffolding yaitu suatu teknik pemberian dukungan belajar yang dilakukan pada tahap awal untuk mendorong siswa agar dapat belajar secara mandiri (Baharudin \& Wahyuni, 2010). Guru memberikan scaffolding dalam penelitian ini dengan cara mencontohkan cara berargumentasi dengan 
menyampaikan pernyataan yang disertai dengan alasan dan bukti, kemudian guru memberikan bantuan berupa mencontohkan cara mengerjakan AfL untuk melatih kemampuan berargumentasi siswa. Hal ini menunjukkan bahwa terdapat peningkatan kemampuan berargumentasi siswa yang dibantu oleh tindakan guru dengan memberikan contoh atau pemodelan argumentasi dan memberikan AfL untuk siswa.

\section{KESIMPULAN}

Berdasarkan analisis hasil penelitian dan pembahasan, dapat disimpulkan bahwa assessment for learning (AfL) berpengaruh terhadap kemampuan berargumentasi siswa. AfL berpengaruh terhadap kemampuan berargumentasi karena secara konten, bentuk soal dan konsistensi pemberian dirancang khusus untuk melatih kemampuan berargumentasi. Selain itu, AfL menggunakan feed back untuk memberikan informasi sebagai bahan refleksi siswa dalam memperbaiki dan meningkatkan kemampuan berargumentasinya. Pelatihan argumentasi menggunakan AfL merupakan aplikasi teori behaviouristik dan teori scaffolding Vygotsky. Kemampuan berargumentasi merupakan kemampuan berpikir yang termasuk dalam aspek penalaran ilmiah dan literasi sains. Oleh karena itu, penelitian ini menunjukkan bahwa AfL yang dapat mempengaruhi kemampuan berargumentasi juga berpengaruh terhadap penalaran ilmiah siswa dan kemampuan literasi sains siswa sekolah menengah atas.

\section{DAFTAR PUSTAKA}

Alfieri, L., Brooks, P.J., Aldrich, N.J., \& Tenenbaum, H.R. (2011). Does discoverybased instruction enhance learning? Journal of Educational Psychology, 103, 1-18.

Aufschnaiter, V. A., Eduran, S., Osborne, J., \& Simon, S. (2008). Arguing to learn and learning to argue: Case studies of how students' argumentation relates to their scientific knowledge. Journal of Research in Science Teaching, 45, 101-131.

Baharuddin \& Wahyuni, Esa Nur. (2010). Teori Belajar dan Pembelajaran. Jogjakarta : Ar-Ruzz Media

Basuki, Ismet \& Hariyanto.( 2014). Asesmen Pembelajaran. Bandung : PT Remaja Rosdakarya

Block, R.M. (2012). A discussion of the effects of openbook and closed-book exams on student achievement in an introductory statistics course. Primus, 22(3), 228-238.

Bricker, L.A. \& Bell, P. (2008). Conceptualizations of argumentation from science studies and the learning sciences and their implications for the practices of science education. Science Education, 92 (3), 473-498.

Chen, Y.C. (2011). Examining the Integration of Talk and Writing for Student Knowledge Construction through Argumentation.Unpublished doctoral dissertation. The University of Iowa, Iowa City, United States of America.

Duschl, RA. (2008). Quality argumentation and epistemic criteria. Dalam S. Erduran \& M.P. Jiménez Aleixandre (Eds.), Argumentation in Science Education: Perspectives from ClassroomBased Research. (hlm. 159-175). Dordrecht: Springer.

Ellis, R. (2009). Corrective feedback and teacher development. L2 Journal, 1, 3-16.

Germer, C.K. (2009). The Mindful Path to SelfCompassion. USA : The Guilford Press

Handayani, Putri \& Murniati, Sardiyanto. (2015). Analisis argumentasi peserta didik kelas x sma muhammadiyah 1 palembang dengan menggunakan model argumentasi toulmin. Jurnal Inovasi Dan Pembelajaran Fisika, 2 (1).

Hattie, J. \& Timperley, H. (2007). The power of feed back. Review of Educational Research, 77, 81112.

McNeill, K.L., \& Krajcik, J. (2011). Assessing middle school students' content knowledge and scientific reasoning through written explanations. Paper Presented at the University of Maine, No Question Left Behind: Bringing Guided Inquiry Curriculum Materials into the Classroom, hlm. 113, University of Maine, Maine, United States.

McNeill, K.L., \& Krajcik, J. (2009). Designing instructional materials to support students' in writing scientific explanations: using evidence and reasoning across the middle school years. Paper Presented at the Annual International Conference Grand Challenges and Great Opportunities in Science Education National Association for Research in Science Teaching Annual, hlm. 1-17, Hyatt Regency Orange County, California.

Moore, J. C. \& Rubbo, L. J. (2012). Scientific reasoning abilities of non-science majors in physicsbasedcourses. American Physical Society, 8(1), 18.

Ng, Eugenia M.W. (2016). Fostering pre-service teachers' self-regulated learning through self- and peer assessment of wiki projects. Computers \& Education, 98, 180-191

Nurgiyantoro, Burhan. (2009). Penilaian dalam Pengajaran Bahasa dan Sastra. Yogyakarta : BPFE

Ormrod, Jeanne Ellise. (2008). Psikologi Pendidikan Jilid 1.Jakarta : Erlangga

Pritasari, A. C., Dwiastuti, S., Probosari, R.M., \& Sajidan. (2015). The argumentation capacity improvement through the problem based learning implementation in class $\mathrm{x}$ mia 1 sma batik 2 surakarta. Jurnal Pendidikan IPA Indonesia, 4 (2), 158-163.

Sadler, T. D., \& Fowler, S. R. (2006). A threshold model of content knowledge transfer for socioscientific argumentation. Science Education, 90, 986-1004.

Schen, M.S. (2007). Scientific reasoning skills development in the introductory biology courses for undergraduates. Unpublished doctoral dissertation. The Ohio State University, Columbus, United States of America

Shute, V.J. (2008). Focus on formative feedback. Review of Educational Research, 78, 153-189. 
Slavin, Robert E. (2008). Psikologi Pendidikan Jilid 1. Jakarta : Indeks

Slavin, Robert E. (2011). Psikologi Pendidikan Jilid 2:Teori dan Praktik. Jakarta : Indeks

Smith, M.K., Wood, W.B. \& Knight, J.K. (2008). The genetics concept assessment: a new concept inventory for gauging student understanding of genetics. CBE-Life Sciences Education. 7, 422430.

Squire, K., \& Mingfong. (2007). Developing scientific argumentation skills with a place-based augmented reality game on handheld computers. Journal of Science Education and Technology, 16 (1).

Stiggins, R., \& Chapuis, J. (2006). What a difference a word makes: assessment for learning rather than assessment of learning help students succeed. Journal of Staff Development, 27(1), 10-14.

Suwandi, Sarwiji. (2011). Model Asesmen dalam Pembelajaran. Surakarta : Yuma Pustaka
Tseng, S.C., \& Tsai, C.C. (2007). On-line peer assessment and the role of the peer feedback: a study of high school computer course. Computers \& Education, 49(4), 1161-1174.

Viyanti. (2015). The profile of argumentation skill using "toulmin argumentation pattern" analysis in the archimedes principal on the students of sma kota bandar lampung. Jurnal Pendidikan IPA Indonesia, 4 (1), 86-89.

Williams, J.B. (2006). The place of the closed book, invigilated final examination in a knowledge economy. Educational Media International, 43(2), 107-119

Zembal-Saul, C. (2009). Learning to teach elementary school science as argument. Science Education, 93(4), 687-719. 